\title{
岩盤不連続体解析に必要とする 不連続面の挙動特性の評価法
}

\author{
蒋 宇静 $^{1} \cdot$ 中川光雄 ${ }^{2} \cdot$ 江崎哲郎 $^{3}$ \\ ${ }^{1}$ 正会員 博(工) 長崎大学助教授 工学部社会開発工学科 \\ ( ₹852-8521 長崎県長崎市文教町 1 - 14) \\ ${ }^{2}$ 正会員 博(工) (株) C R C 総合研究所 関西支社課長役 \\ ${ }^{3}$ 正会員 工博 九州大学教授 工学部附属環境システム科学研究センター
}

\begin{abstract}
不連続性岩盤内に立地する岩盤構造物の变形挙動や安定性を, 不連続体解析手法を用いて適切に評価し, 調査・設計へ導入するには，岩盤不連続面の変形・強度特性を正確に表現する不連続面挙動モデルと挙動を 規定する特性值の決定が不可欠となる，本論文は，岩盤不連続面の力学的挙動特性を室内試験により求め る方法を基本として, 個別要素法などの不連続体解析手法のための不連続面挙動モデルとその特性値を決定 する一連のプロセスを示す.また, 代表的な特性值の 1 つであるせん断剛性を, 実際のせん断挙動を忠実に 評価するために非線形として取り扱った場合の，変形挙動に与える影響を明かにすることを試みる。
\end{abstract}

Key Words : discontinuities, mechanical behavior, shear test, evaluation method, numerical simulation

\section{1.はじめに}

地下発電所などの大規模地下空洞や斜面, ダム基礎 など岩盤構造物の安定性を数値解析を用いて評価し， これを調査・設計へ有効に反映させるには，如何にし て信頼性のある不連続面挙動モデルを構築して妥当性 のある結果を得るかが課題となる, 岩盤構造物の力学 的安定性を論じるには, 多くの場合, 岩盤を構成する 岩石基質部よりもむしろ岩盤内に含まれる不連続面の 変形·強度特性に大きく支配されることを念頭におか ねばならない.不連続性岩盤を対象とした解析手法の 内, 特に岩盤中の不連続面を一つ一つ具体的に表現す る不連続体としてモデル化するアプローチを考える場 合，不連続面の幾何学的分布特性を把握すると同時 に, 単一不連続面の力学的挙動特性を正しく評価する ことが重要となる.今日ではコンピュー夕技術の飛躍 的な進歩により, 岩盤構造物の合理的な設計・施工を 実現すべく, 実務的にもキーブロック理論, 個別要素 法,不連続変形法をはじめとする不連続体解析手法を 用いて岩盤の挙動を評価する試みが数多く見受けられ るようになった。

さて, 不連続体解析手法の中で, 不連続面を要素境 界として取り扱い,ここに不連続面の挙動モデルを組 み込んだ個別要素法の適用がある。ここ数年の国内お よび海外の個別要素法 (例えば, UDECコード1) を
用いた解析例21-10) を調べてみると, 大半は実際の問 題を対象としながら，不連続面の挙動モデルの選定 やこれに対応する特性值の決定方法が必ずしも明確 に示されていない.Coulomb滑りモデルと呼ばれる 図一1のようなモデルが不連続面の代表的な挙動モ デルとして挙げられ, その特性值には, せん断応力が せん断強度に至るまでの剛性を規定するせん断剛性 $(K s)$, せん断強度を規定する粘着力および内部摩擦 角 $(C$ と $\phi)$, 世ん断変位に伴う垂直变位の変化を規 定するダイレーション角 $(i)$ がある ${ }^{1}$.このモデル は, 各特性值の物理的意味が明確で理解し易く, せ ん断剛性は，せん断強度に至るまでおよび降伏後の 徐荷・再載荷過程において線形として簡便に取り扱 われることが多いため, 従来より慣用的に用いら れ，前述の解析例21-10)においてもその適用が見受け られる。解析結果の信頼性と実用性は, 不連続面の 挙動モデルの選定や対応する特性值の決定の的確さ に直接に依存するため, 実際の現場の条件を反映さ せた状態で不連続面の力学的特性を忠実に求めるこ とが，有効な解析の実施に対して最も重要であると 考える.

ところで，自然界における岩盤不連続面の挙動特 性は, その表面の特徵や開口性, 挟在物, せん断履歴, 垂直応力など, 多くの要素に影響されるため,これら を全て含めた理論的検討や原位置試験は非常に困難 
であり,様々な条件が比較的自由に設定できる室内試 験によって求めるべきものであると考える。この考え 方を基本として, 本論文は, 不連続体解析に必要とす る不連続面の挙動特性を決定する処理手順を

(1) 力学特性試験による岩盤不連続面の力学的挙動 特性の把握 ;

(2)試験結果に基づく不連続面の挙動モデルの選定, およびそれに対応する特性值の評価と決定

のように考え, 各項目の具体的な処理方法を示す.そ して,この決定手順に従って, 実際の現場で採取され た数種類の自然の岩盤不連続面の供試体を用いて実施 した室内試験の結果を利用して, 特性值を定量的に決 定する方法を示す。さらに，代表的な特性值の 1 つ で, 慣用的に線形として取り扱われることの多いせん 断剛性を, 実際のせん断挙動を忠実に評価するために 非線形として取り扱った場合の, 変形挙動に与える影 響を明かにすることを試みる。

本論文に示す岩盤不連続面の特性値を決定する一連 のプロセスは, 従来から個別要素法など不連続体解析 手法の適用上の課題とされてきた「原位置岩盤不連続 面の挙動特性の適切な定量的評価」を実現する実用的 な手法として期待され, 不連続性岩盤の解析的な評価 の信頼性の向上に寄与すると考えられる.

\section{2. 特性値の定量的評価プロセスの概要}

岩盤不連続面の変形·強度特性値を定量的に評価す るための前述した処理(1)と(2)をさらに具体的に分割 し, 一連のプロセスを示すと, 図一2のようになると 考える。このプロセスでは，岩盤不連続面に関する 原位置の情報を取得する手段として不連続面の室内女 ん断試験の利用を前提としている点に特徴がある。不 連続面の状況は現場によって様々であり, 複雑な分布 や特性を有するので, 変形特性や強度特性を室内試験 によって把握することが今までにも多く実施されてき た (1)-13). 著者らが開発した直接せん断試験装置を用い る室内試験では, 要求される応力や变形を適当に再現 し, それらを計測できる特徽を有することから, 複雑 な応力状態とせん断履歴を受ける原位置不連続面の挙 動特性を正しく評価することが可能である．さらに， 不連続体解析において従来よりあまり明確に言及され てこなかった不連続面の挙動モデルを選定するという 行為は, 原位置不連続面の挙動特性をモデル化する第 一歩として重要であり, 岩盤構造物の解析モデルの妥 当性や得られた解析結果の信頼性に大きな影響を与え る. 尚, 不連続面の挙動モデルの選定は, 室内試験の 結果およびその評価に基づき適切に判断されるべきと 考える。

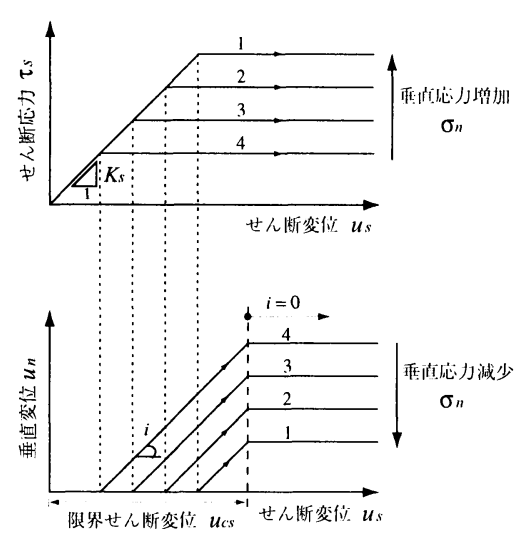

図一 1 Coulomb滑りモデル

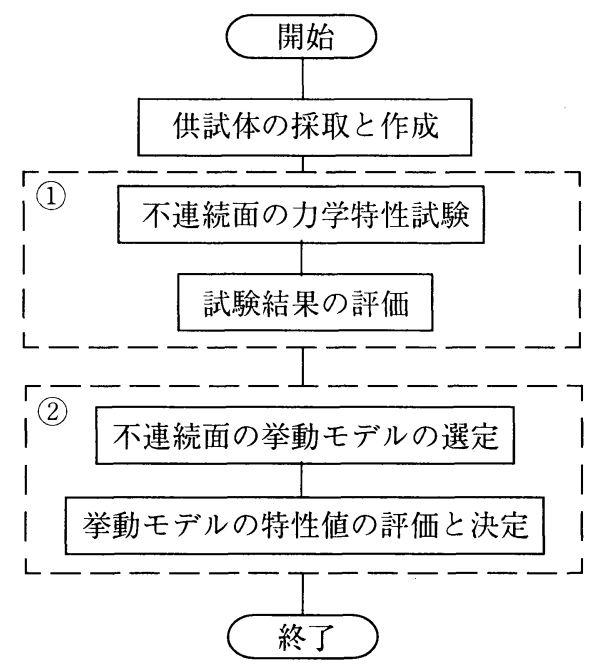

図－2 不連続面の挙動特性の評価と モデル化のプロセス

\section{3. 不連続面の力学特性試験}

本章では,図ー 2 に示した各処理の内, 供試体の採 取から試験方法までを述べる。

\section{（1）供試体の作製方法}

岩盤不連続面の挙動特性を求める目的で, 現場か ら自然不連続面を含む供試体を採取する，供試体の 作成には，地表や調査横坑内あるいは施工中の地下 空洞内であれば自然不連続面を含む岩片やボーリン グコアが利用される。採取においては，現場の状態を 維持するために岩石の含水状態や不連続面のかみ合 い状態を変化させないように注意を払う必要がある。 
採取された供試体は, 図ー 3 に示すように, 供試体 の中央位置に不連続面が入るように次の手順でせん 断試験用の型枠に埋め込む ${ }^{14)}$.

1) 供試体を採取したままの状態で粘着テープで 固定し, 埋め込み用型枠に合うように岩石カッター で適当な寸法に整形する。型枠にはみぞ型鋼を利用 しており，その外寸法は $148 \times 130 \times 61.5 \mathrm{~mm}$ である.

2 ) 型枠の両側面にテフロンシートを貼ったプ レートを取付け，そこに埋め込み材料を流し込んで 供試体の下部を固定する。このプレートは埋め込み 材料の流出を防止し,また, 型枠上下のズレを解消す る役割を果たす。埋め込み材料にはエポキシ樹脂と 珪砂を $1: 2$ の比で混合したSBモルタル（ショーボン ド社製，硬化時の圧縮強度約 50MPa）を用いる。 ま た，不連続面への埋め込み材料の侵入を防ぐために， 幅 $10 \mathrm{~mm}$ のバンテージを不連続面に沿って巻く。な お, 供試体を埋め込む際, 不連続面の推定されるすべ り方向が型枠の長手方向, つまり, せん断方向に一致 するように留意する.

3 ) 同様の方法で供試体の上部を固定する。 その 際, 上下部間に一定の隙間を確保するために幅 $10 \mathrm{~mm}$ のスペイサーを用いて, 全体を逆さまに置く. 埋め込 み材料が硬化した後，スペイサーおよび両側面のプ レートを取外し, テープ,バンテージなどをカットし て不連続面を露出する.

以上の手順で, 試験に必要な個数の不連続面の供 試体を作製する. 写真一 1 と 2 に, 自然の岩盤不連続 面を内包する溶結凝灰岩と砂岩の供試体を例示する.

\section{(2) 力学特性試験の概要}

単一不連続面の力学的特性に関する代表的な室内 試験法をまとめると, 表一 1 のようになる.

まず，垂直載荷における不連続面の変形挙動は, 一例として図ー4 に示すように ${ }^{15)}$ ，16)，不連続面を含 む供試体の垂直変位から岩石基質部の垂直変位を差 引いて, 不連続面の垂直挙動を表す曲線が得られ る.この曲線を模式化する 2 種類の代表的な数学的 モデルが提案されており，一つはGoodmanとBandisに よって示された双曲線関数式 111，17，もう一つは, BrownとScholzの対数関数式 ${ }^{21}$ である.これらのモデ ルでは応力と変形の関係が与えられた関数形に規定 され包括的に示されており, 必ずしも実際の不連続 面自体の特性が忠実に表現されているわけではな い.

次に, せん断載荷を受ける不連続面を含む供試体 は, 垂直応力 $(\sigma n)$ が一定の状態か，または垂直剛 性 $(K)$ が一定の状態下におかれる。前者は, 岩盤斜 面の表面付近や浅いところに位置するなど, 周辺か

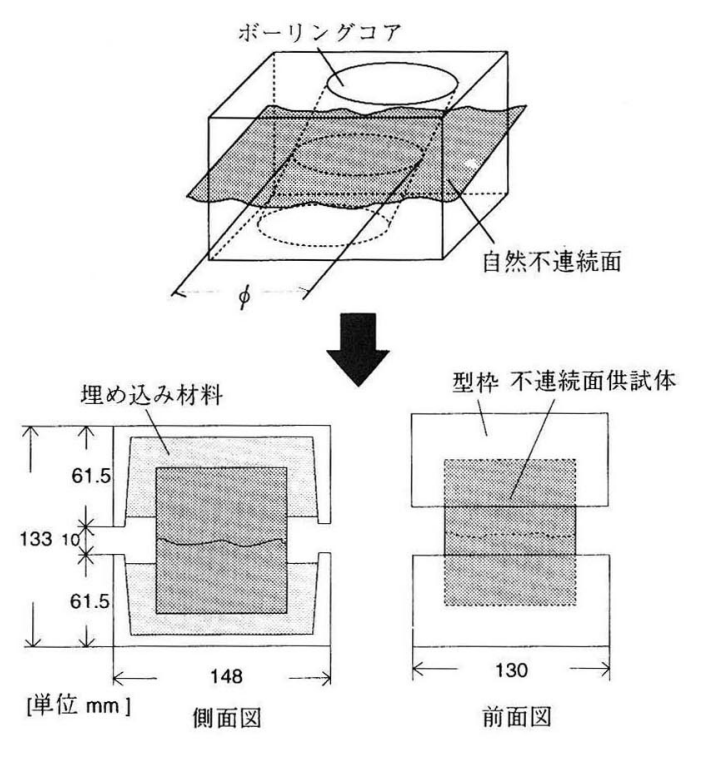

\section{図－３，自然の岩盤不連続面供試体の設定}

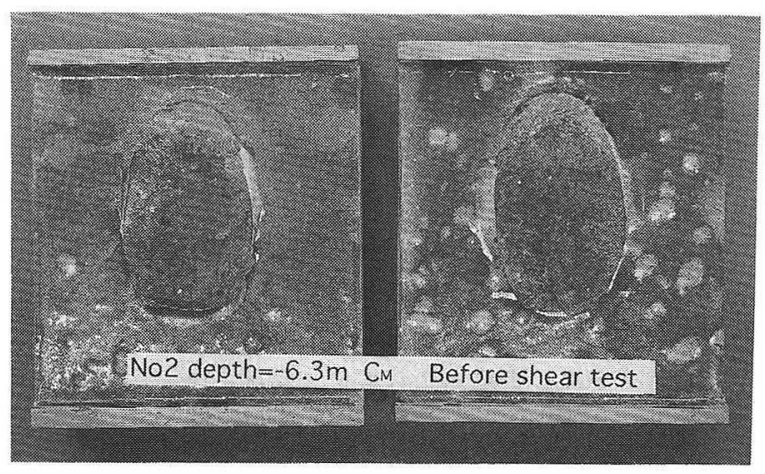

(溶結凝灰岩)

写真ー 1 ボーリングで採取した自然の岩盤不連続面の 試験供試体（左は下面，右は上面）

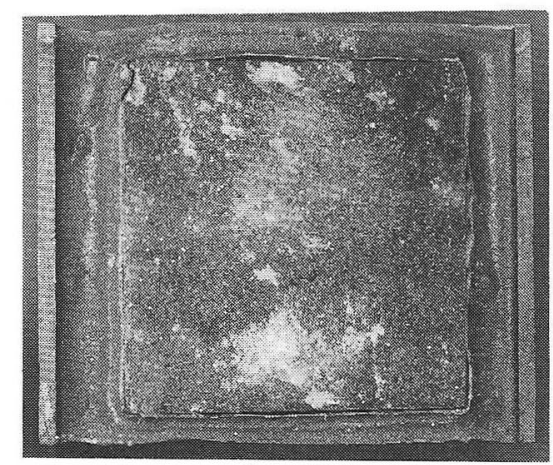

(砂岩)

写真一2 岩塊に内包した自然の岩盤不連続面の 試験供試体（下面） 
らの拘束が低い場合 $(K=0)$ を, 後者は, ロックボ ルトで補強された場合や比較的深部に位置する場合 を意味する.図ー 5 に模式的に示したように，垂直 剛性制御の場合では, 甘ん断履歴を受けていない不 連続面が $K=0$ の条件においてピークせん断強度を示 すが, 垂直剛性が増大するに連れてピークせん断強 度を示さなくなり，また，せん断に伴うダイレー ションも小さくなることが分かる ${ }^{13)}$.

著者らは, 垂直応力を一定に保つ状態において, 塑 性流動となる大変形 (最大せん断変位 $20 \mathrm{~mm}$ ) まで不 連続面のせん断特性を求めることのできる直接せん 断試験装置を開発した。この試験装置は, 大別して直 接せん断装置部と計測・制御装置部からなる ${ }^{18}$.

\section{a ）直接せん断装置}

せん断容器は下箱が移動する構造になっており, 上箱はせん断容器を挟込む形で設置されたロッドに よって支持されている、ロッドは十分長く, 両端取付 部がリンク構造で上箱の上下移動および回転が自由 に許されるが水平方向の動きは拘束されている. 載 荷はせん断方向, 垂直方向ともに油圧サーボ方式で ある. 最大載荷能力は, せん断載荷は前進方向約 $400 \mathrm{kN}$, 後退方向約 $350 \mathrm{kN}$ であり, 垂直載荷は約 $2 \mathrm{MN}$ である。

\section{b）計測・制御装置}

上箱の垂直変位および回転変位は, 上箱の 4 隅に 設置した高精度変位計を用いて計測する。また，せん 断変位は上箱と下箱の間に取り付けた変位計によっ て計測される.荷重および変位に関するデータはデー タロガーを経由して自動記録される。

\section{（3）自然の岩盤不連続面の試験方法}

自然の岩盤不連続面の力学的特性試験法は, 先に 述べた方法で作成された供試体を直接せん断試験装 置のせん断箱に設置した後, せん断変位を与えない 初期状態で, 不連続面供試体と岩石基質部の垂直剛 性試験をそれぞれ行う。最大垂直応力は掘削や施工 などによる地山応力の再配分を考慮して，供試体を 採取した深度から計算した垂直応力の 2 倍以上と設 定すべきと考える. 次に, せん断試験を行う. 不連続 面の賦存状況に基づき不連続面に作用する垂直応力 を設定し, それを一定に保ちながら, 残留強度も求め られるように，最大 $20 \mathrm{~mm}$ までせん断変位を与える。

垂直応力やせん断履歴などによる影響を調べるに は, 同じ試験体を数個用意し, 垂直応力を変化させて 同様のせん断試験を行う.また, せん断変位に伴う垂 直変位の変化を規定するダイレーション角を正確に 決定するには，試験体埋め込み時に生じた不連続面 の傾きの補正を行う必要があり, せん断試験終了後
表一１不連続面の力学特性試験法

\begin{tabular}{|c|c|c|}
\hline テストタイプ & 測定変数/テスト条件 & 特性值 \\
\hline 垂直載荷試験 & $\begin{array}{l}\text { 垂直応力 } \\
\text { 垂直変位 }\end{array}$ & 垂直剛性 $K_{n}$ \\
\hline $\begin{array}{l}\text { 垂直応力一定 } \\
\text { 下における直 } \\
\text { 接せん断試験 }\end{array}$ & $\begin{array}{l}\text { せん断応力 } \\
\text { ダイレーション } \\
\text { せん断変位 } \\
\text { 垂直変位 }\end{array}$ & $\begin{array}{l}\text { せん断剛性 } K s \\
\text { 摩擦角 } \phi \\
\text { せん断強度 } \sigma s p \\
\text { ダイレーション角 } i\end{array}$ \\
\hline $\begin{array}{l}\text { 垂直剛性 }(K) \\
\text { 一定下におけ } \\
\text { る直接せん断 } \\
\text { 試験 }\end{array}$ & $\begin{array}{l}\text { せん断応力 } \\
\text { 垂直応力 } \\
\text { ダイレーション } \\
\text { 垂直変位 } \\
\text { せん断変位 }\end{array}$ & $\begin{array}{l}\text { せん断剛性 } K s \\
\text { 摩擦角 } \phi \\
\text { せん断強度 } \sigma s p \\
\text { ダイレーション角 } i\end{array}$ \\
\hline
\end{tabular}

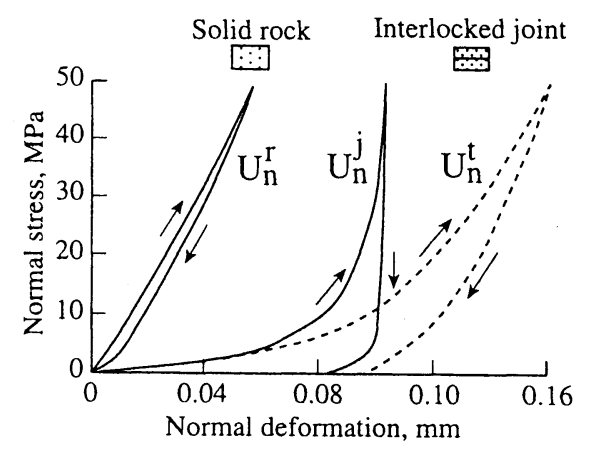

図-4 垂直載荷における不連続面の変形挙動

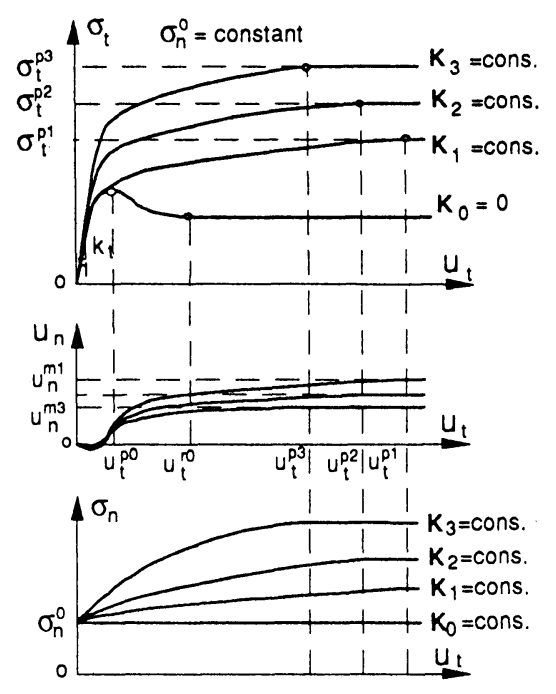

図一 5 垂直剛性制御下における不連続面のせん断挙動 $\left(\mathrm{K}_{3}>\mathrm{K}_{2}>\mathrm{K}_{1}>\mathrm{K}_{0}=0\right)$ 
に不連続面の表面形状の計測をせん断方向に沿って 行い, せん断方向に対する不連続面の傾斜角を求め る。具体的な補正方法は後述する。

\section{4. 岩盤不連続面の力学的挙動モデルの選定}

実際の岩盤不連続面は，その表面形状に様々な凹 凸特性を有するので, せん断機構は，せん断初期の 凹凸の乗り上げに始まり，凹凸表面の摩耗さらには 凹凸の破壊へ進行すると考えられる ${ }^{19)}$ 。このよう に, せん断挙動が凹凸の変化, すなわち表面損傷に 関連することに基づけば，如何にしてせん断に伴う 表面損傷を定式化に取り入れるかが単一不連続面の 力学的挙動モデルを設計する上で重要となる。

一方, 表面損傷は, 初期の凹凸状態やせん断履 歴, 垂直応力の大きさ，せん断変位のそれぞれに関 連し20), これらによる効果として, せん断剛性, せ ん断強度, ダイレーション角などに影響を与えると 考えられるが，表面損傷は非常に複雑な現象であ り，故にその定量化が困難であることもあり，未だ 完全な挙動モデルが存在するとは言えない.

現在までに提案されている単一不連続面に対する 力学的挙動モデルを, 不連続面の表面の凹凸特性や 損傷の取り扱い方法の相違により, 以下に示す $3 つ$ のグループに分類することができる.

グループ A：不連続面の表面の複雑な凹凸形状を 理想化することによりその力学的挙動を理論的に検 討したモデル。このグループに属するモデルは結果 の信頼性が理想化の妥当性に大きく依存すると考え られる。

グループB：不連続面の初期の凹凸，せん断履歴な どにより独自性のある表面特性の影響を受ける個々 の不連続面の挙動特性の反映を試みたモデル。

グループC：過去の多くの室内試験結果や原位置試 験結果をもとにした経験的な定式化により，多くの 不連続面の挙動特性の包括的な表現を試みたモデル.

ここ最近, 個別要素法をはじめとする各種の不連 続体解析手法に組み込まれ, 室内試験の結果との比 較が示されている各グループの代表的な挙動モデル とその特徴を表一 2 に示す。ここで,グループBにお ける挙動モデルの特性值の決定は, 前章で述べた室 内せん断試験の結果を必要とする。また, グループC に属するBartonらのモデルは，独自に指定された試験 方法により特性値を決定するが，室内試験のスケー ルで結果の妥当性を検証するには, 前章で述べた室 内せん断試験の結果を必要とする。

さて, 不連続面の挙動モデルの役割は, 基本的に は自然の岩盤不連続面の挙動特性を忠実に表現する
表ー2 不連続面挙動モデルの分類

\begin{tabular}{|c|c|c|}
\hline グループ & 提案者 & 特 \\
\hline A & Plesha ${ }^{19)}$ & 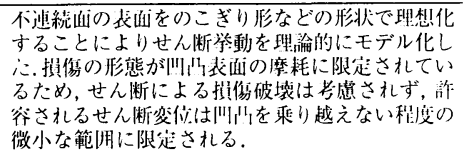 \\
\hline \multirow{4}{*}{ B } & Coulomb $b^{211}$ & 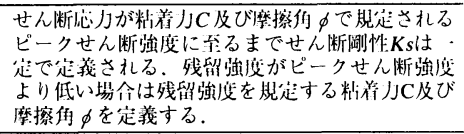 \\
\hline & $\begin{array}{l}\text { Saeb \& } \\
\text { Amadei }^{22}\end{array}$ & 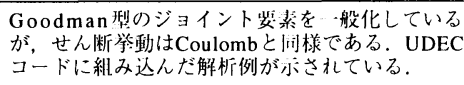 \\
\hline & $\begin{array}{l}\text { Cundall \& } \\
\text { Lemos }^{23} \text { ? }\end{array}$ & 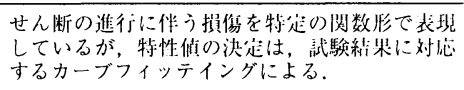 \\
\hline & $\begin{array}{l}\text { 中川 } \\
\cdot \text { 蒋24)-26) }\end{array}$ & 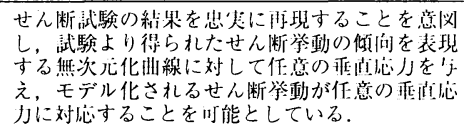 \\
\hline $\mathrm{C}$ & Barton $^{16}$ & 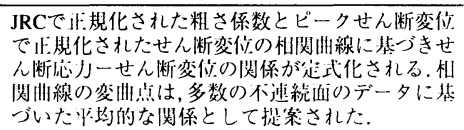 \\
\hline
\end{tabular}

ことにある。これは, 挙動モデルが前章で述べた力 学特性試験の結果を忠実に再現し, 垂直応力依存 性, 寸法効果を考慮できることを意味する，以下 に，挙動モデルの選択において考慮すべきと思われ る点を挙げる。

a) 力学特性試験の結果を忠実に反映できる定式化 を有すること.

b）載荷のみならず, 徐荷, 再載荷, 繰返し載荷な どのシミュレーションの過程における不連続面の挙 動を適切に表現できること.

この場合, 力学特性試験の結果を反映させるため に，理論的に高精度なモデルの適用より比較的単純 なモデルを適用しても所要の精度が満たされた場合 は, 単純なモデルを選択すべきであろう.例えば力学 特性試験で得られたせん断挙動においてピーク時ま では線形的な挙動を示し，ピーク後もピーク強度と 残留強度に何ら差が見られない場合はCoulomb滑りモ デルで十分であると判断する。

せん断に伴う表面形状の変化を包括的に表現する アプローチとして, 著者らは, 不連続面の室内せん 断試験結果を忠実に再現することを意図して定式化 した挙動モデルを提案している 24), 26)。この提案で は, 不連続面の室内せん断試験の結果において, せん 断応力 $\tau$ をピークせん断応力 $\tau_{p}$ で, また, せん断変 位 $U_{s}$ を $\tau_{p}$ に対応するせん断変位 $U_{p}$ で無次元化す る操作を各垂直応力毎に実施し, 図一6に示すような $\tau / \tau_{p}$ と $U_{s} / U_{p}$ の相関関係を得る。なお, $\tau_{p}$ が明確でな い場合は, 残留応力と残留応力に至った時点のせん 


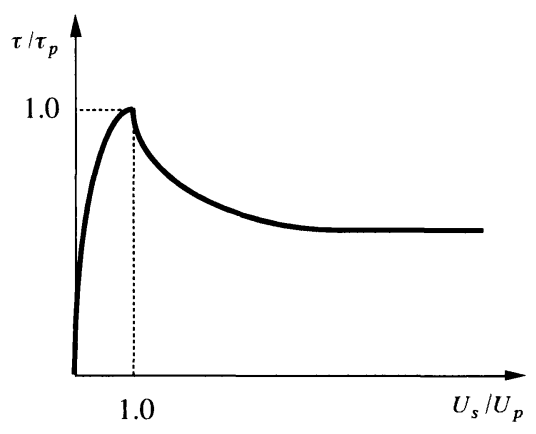

図ー6 ピーク時のせん断変位とせん断応力で 無次元化したせん断挙動曲線

断変位を用いる方法が考えられる.式（1）に示す定 式に任意の垂直応力 $\sigma_{n}$ を与えることにより，モデル 化されるせん断挙動が任意の垂直応力に対応するこ とを可能としている.

$$
\tau=\mathrm{B} \sigma_{n} \cdot \eta_{p}\left(\sigma_{n}\right)
$$

ただし $, \mathrm{B}=\tau / \tau_{p}=\operatorname{Table}(\mathrm{A}), \quad \mathrm{A}=U_{s} /\left(U_{p}\right)_{r e p}$

ここで, $\tau$ はせん断応力, $\tau_{p}$ はピークせん断応力, $\sigma_{n}$ は垂直応力, $U_{s}$ はせん断変位, $\left(U_{p}\right)_{r e p}$ は各々の垂直 応力レベルに対応する $U_{p}$ の代表值; Table(A) は表一 3 において $\mathrm{A}$ 列の数值を $\mathrm{B}$ 列の数值に対応させる操作； $\eta_{p}\left(\sigma_{n}\right)$ は任意の垂直応力における $\tan \phi_{p}$ を意味し, 試験 結果における $\sigma_{n}$ と $\tan \phi_{p}$ の関係を表わす近似式であ り; $\phi_{p}$ はピーク時の摩擦角を表す.

以上より，せん断に伴う表面損傷に基づいた前述 の影響要因（不連続面表面の初期の凹凸状態，せん 断履歴, 垂直応力, せん断変位など）が比較的忠実 に定式に反映されると考える26).ここに示した定式は 個々の不連続面の除荷 - 再載荷過程においても同様 に適用すると考えられる。ただし，繰り返しせん断 時のモデル化などについては別に検討する必要があ る.

\section{5. 不連続面の挙動モデルの特性值の決定法}

不連続体解析を行うのに必要とする不連続面の力 学的特性值は実際に用いられる挙動モデルによって 違う。ここでは，図一１に示したようなCoulomb滑 りモデルを用いた場合, 垂直剛性, せん断剛性, ダ イレーション角, 粘着力と摩擦角があり, 以下にこれ らを前述した室内試験方法に基づいて求める方法を 示す ${ }^{14)}$.
表一 3 係数 $\mathrm{A}$ と $\mathrm{B}$ の数列表示

\begin{tabular}{c|c}
\hline $\mathrm{A}$ & $\mathrm{B}$ \\
\hline$U_{s} /\left(U_{p}\right)_{\text {rep }}$ & $\tau / \tau_{p}$ \\
\hline 0.0 & 0.0 \\
$\cdot$ & $\cdot$ \\
$\cdot$ & $\cdot$ \\
$\cdot .0$ & 1.0 \\
$\cdot$ & $\cdot$ \\
\hline
\end{tabular}

\section{（1）力学的特性値の決定方法}

\section{a ）垂直剛性 $K n$, せん断剛性 $K s$}

$K n$ と $K s$ は, 不連続面が垂直方向，あるいはせん断 方向に変位を起こしにくさを評価する指標であり， それらに影響を与える代表的な要素として，垂直応 力，不連続面の粗さ，凹凸壁面の強度が挙げられる。 一般的な定義によれば, それぞれ垂直方向変位, せん 断方向変位の増分に対する垂直応力, せん断応力の 増分の比となる。

$K n$ の算定には，図ー4に示したように試験体の垂 直変位から岩石基質部の変位を除去した不連続面自 体の垂直応力ー垂直変位曲線を双曲線関数，または 2 次式, 1 次式で回帰分析する方法がある. 初期の垂 直変位のみを対象とする場合は $K n$ を近似的に線形と して取り扱うことが多く，この場合，双曲線または 2 次式で回帰分析した場合に対しては，現場で考えら れる平均的な垂直応力についての微分係数を $K n$ と し，また，1 次式で回帰分析した場合に対しては，そ の直線部の傾きを $K n$ とすればよいと考える.しかし， 高い圧縮応力を受ける不連続面は基本的にはその圧 縮が回復できず，また著しく非線形な変形を示すた $め^{20)}$, 垂直剛性の垂直応力依存性の評価にはまだ検 討の余地が残されている.

$K s$ の算定は，ピーク時まで線形として取扱う場合， せん断応力一せん断変位曲線上のある点の接線の傾 きを求めることで定義するlocal modulus法と，原点と 曲線上のある点を結んだ直線の傾きを求めることに よって定義する secont modulus法がある，せん断変位 に伴いせん断応力がピークを示す場合は，一般的に は, secont modulus法により原点とピーク点を結ぶ傾き を Ks とする。ピークを示さない場合は, 経験的に残 留せん断応力の半分の点と原点を結んだ直線の傾き を $K s$ とすればよいと考える，なお，垂直応力の大き さや凹凸の損傷状態にもよるが，ピークに達するま でのせん断応力とせん断変位との間には，非線形的 な関係を示すことが実験的に明らかにされており ${ }^{14) ，}$ 
この非線形性とそれが不連続性岩盤の変形挙動に及 ぼす影響効果の考察については, 次章で詳述する。

$K n$ と $K s$ との間では, 不連続面と岩石が線形弾性 状態にある場合，次式のような関係がある.

$$
\frac{K_{s}}{K_{n}}=\frac{\tau / u_{s}}{\sigma_{n} / u_{n}}=\tan (i) \tan (\phi)
$$

摩擦角 $\phi=30-50^{\circ}$, ダイレーション角 $i=3-5^{\circ}$ と すると, 垂直剛性がおよそせん断剛性の $10 \sim 35$ 倍と なる、しかし, 実際の岩盤不連続面がせん断過程にお いて凹凸の損傷破壊を生じるため, 単純に式 $(2)$ に 基づいて 2 つの剛性の関係を決められないことは, 次節以降に示す試験結果に基づいて論じる.

b）ダイレーション角 $(i)$

ダイレーション角 $i$ は, せん断変位の増分 $(d U s)$ に対する垂直変位の増分 $(d U n)$ の比であると定義さ れ，不連続面の粗さを評価する 1 つの指標である.こ こでは, 垂直変位一せん断変位曲線から, ピークせん 断応力の位置の接線の傾き，もしくは残留応力に至 る位置の傾きで算出する.試験体を埋め込んだ時, せ

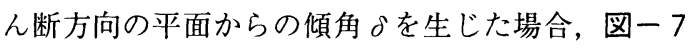
に示したように，垂直変位一せん断変位関係曲線の 接線の傾き $(d U n / d U s)$ から求まった角度に $\delta$ を加 算して補正することにより真のダイレーション角が 求まる.ただし, 図一 7 に示した傾きと反对方向に傾 いた場合は $\delta$ 差し引くことになる.なお， $\delta$ の決定 について, せん断試験終了後に不連続面の表面形状 の計測をせん断方向に沿って行い, せん断方向に対 する不連続面の平均的傾斜角を求める。

\section{c) 粘着力 $C$ と摩擦角 $\phi$}

不連続面のせん断強度を規定するC と $\phi$ は, せん断 応力と垂直応力との関係から求められる. 各試験条 件下でのピーク時および残留時のせん断応力（ $\tau p$, $\tau r)$ と垂直応力 $\sigma n$ との関係を直線回帰し, この直 線の $\tau p, \tau r$ 軸における切片をそれぞれピーク時と 残留時の粘着力 $(C p, C r)$, 傾きをそれぞれピーク 摩擦角と残留摩擦角 $(\phi p, \phi r)$ とする. $C$ と $\phi$ は, 特に掘削などによる不連続面の緩みを考える岩盤空 洞や斜面の安定機構において最も支配的な特性值で あり, 安定性に着目する解析では, $C_{r}, \phi r$ を入力 值とすべきであろう．残留状態を判断しにくい場合 は, せん断変位に対するダイレーション（垂直変位） の変化率がゼロとなる点を残留開始時点として判断 する方法がある271・

一方, Hencher ら 277, 28) は, 粘着力をゼロと設定し て直線回帰分析により摩擦角のみを求める考えを示 した.この設定は, 不連続面が比較的滑らかな場合や

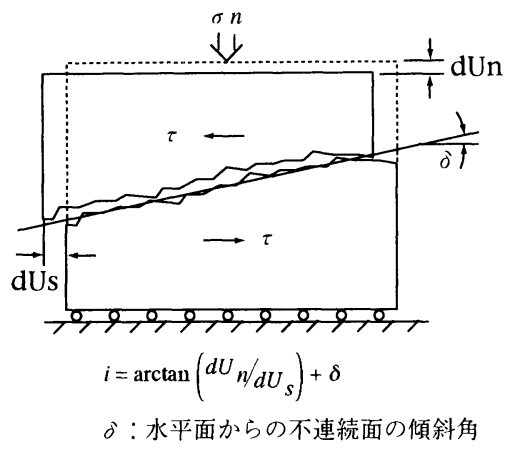

図ー7 ダイレーション角 $(i)$ の補正方法

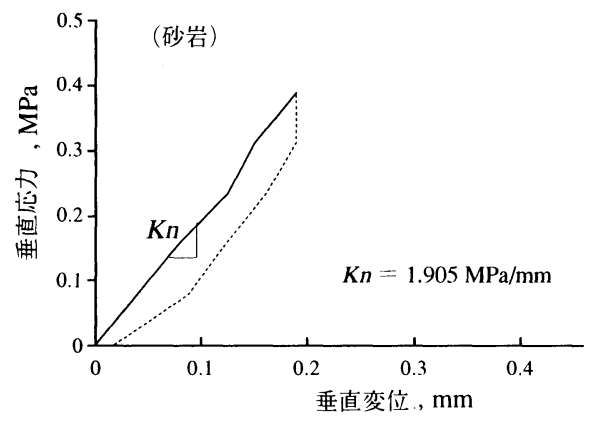

図-8 自然不連続面の垂直載荷変形曲線

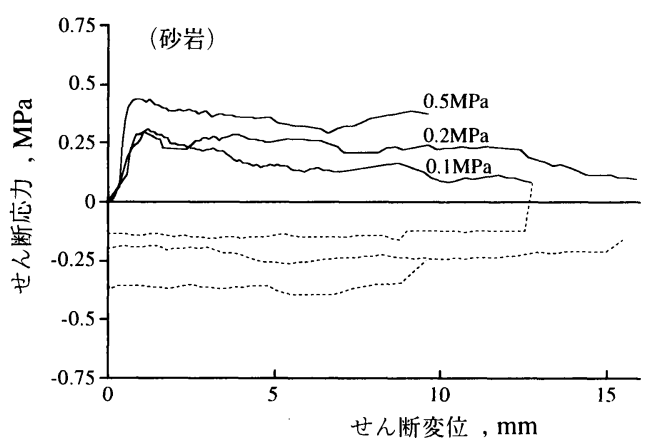

(a)

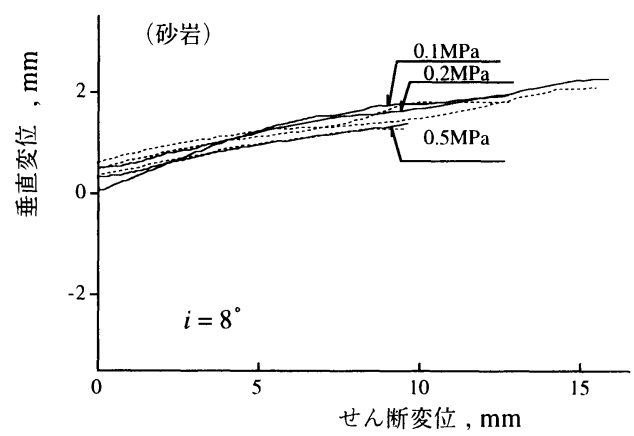

(b)

図ー9 自然不連続面のせん断強度とダイレーション 


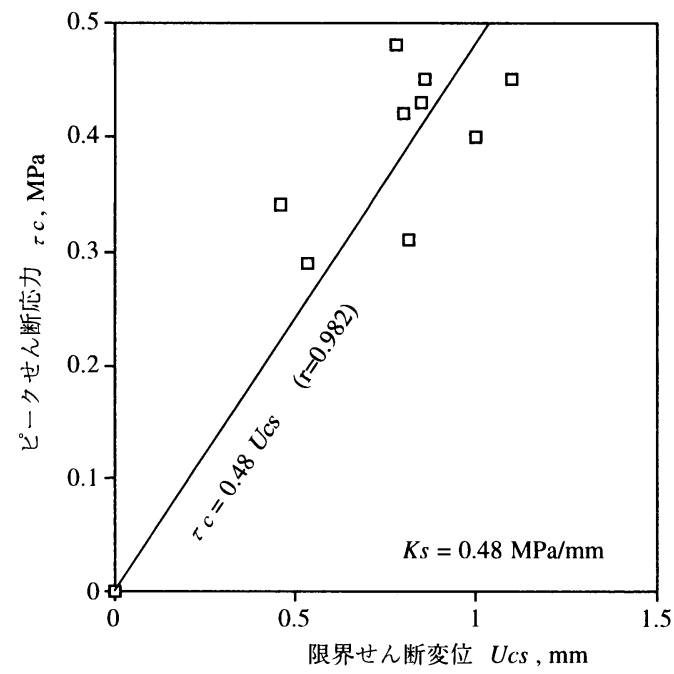

図ー 10 ピークせん断応力とせん断変位の関係

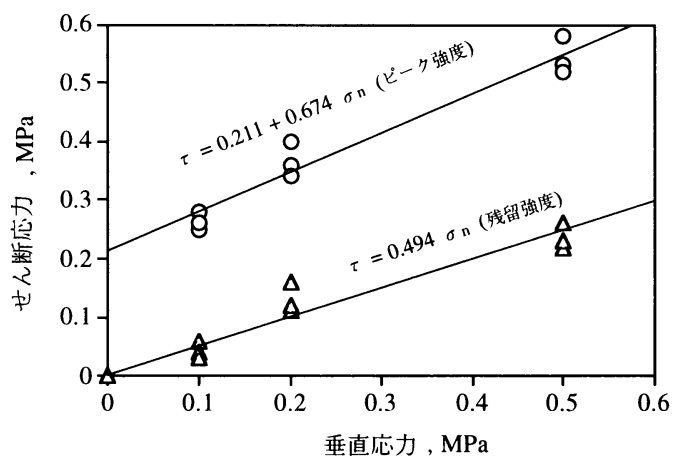

図ー1 1 試験による垂直応力とせん断強度の関係

すでに緩んだ場合に適すると考えられる。

\section{（2）力学的特性值の決定例}

著者らは, 変形や安定性が問題となっている数地 点の岩盤斜面および地下空洞の挙動を数値解析に よって事前に評価するために, 基質部が砂岩, 頁岩, 溶結凝灰岩および花崗岩から成る十数種類の自然不 連続面をボーリングなどで採取し，前章に示した試 験方法によってそれぞれの力学特性および相互関係 を調べている.図ー8 と図ー9には, ある現場斜面か ら採取してきた砂岩不連続面の試験結果の一部14)を 示す. 現場では斜面付近において不連続面に約 $0.1 \mathrm{MPa}$ 程度の垂直応力が働いていると予測された. 垂直応力制御によるせん断試験では, 不連続面の垂 直剛性などの特性値を求めるために垂直応力を最大 で $0.5 \mathrm{MPa}$ まで実施した。

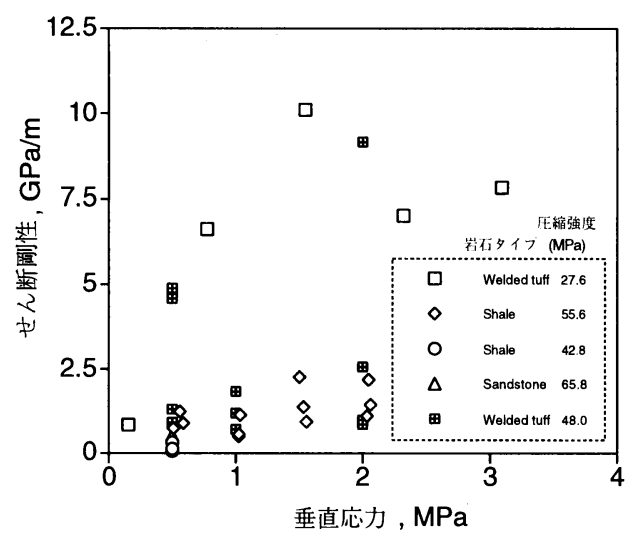

図ー12 試験による垂直応力とせん断剛性の関係

図ー8から分かるように, 低い垂直応力では垂直 応力と垂直変位の関係がほぼ直線的であるため, 原 点を通る 1 次式で回帰分析して，その傾きから垂直 剛性 $(K n)$ を $1.905 \mathrm{MPa} / \mathrm{mm}$ と求めることができた.

図ー9(a)から分かるように, ピークせん断応力まで の段階では, せん断変位とともにせん断応力が非線 形性的に増加するため, せん断剛性が非線形性を示 すことになる。ここでは，せん断応力一せん断変位 曲線上の原点とピーク点を結ぶsecont modulus法を用 いてせん断剛性を求めると, 図一 10 のようにな り, 各垂直応力におけるピークせん断応力とそれに 対応するせん断変位をプロットし，原点を通る 1 次 式で回帰分析して, その傾きから, $K s=0.48 \mathrm{MPa} / \mathrm{mm}$ と求めた。つまり，Kn $\fallingdotseq 4 K s$ である。なお, 図一 9 (a)に示したようなせん断剛性の非線形性の取扱い 方とそれによる岩盤の変形挙動に及ぼす影響効果に ついては後述する。

垂直変位一せん断変位の関係曲線は, いずれの垂 直応力でもダイレーションの傾向を示し，その傾き からダイレーション角 $(i)$ を平均で $8^{\circ}$ と求めた.

また，せん断応力一せん断変位の関係を考察して みると, 垂直応力の増加に伴い明瞭ではなくなるも のの, せん断変位 $1 \mathrm{~mm}$ 付近でピークが示され, せん 断変位の進行とともにせん断応力が残留せん断応力 に達している．各々の垂直応力でのピークと残留強 度を回帰分析することによりピーク強度および残留 強度に対応する粘着力と摩擦角を求めることができ る.ただし, 残留強度については，すでにせん断履歴 を受けているため, 粘着力をゼロとして, 摩擦角を求 めるための線形回帰分析を行う. 図一 11 では, 実験 結果の一例として, ピーク強度時の粘着力と摩擦角 $(C p$ と $\phi p)$ を $0.211 \mathrm{MPa}, 34^{\circ}$ と, 残留強度時の摩 擦角 $(\phi r)$ を $26.3^{\circ}$ と線形回帰分析で求めること 


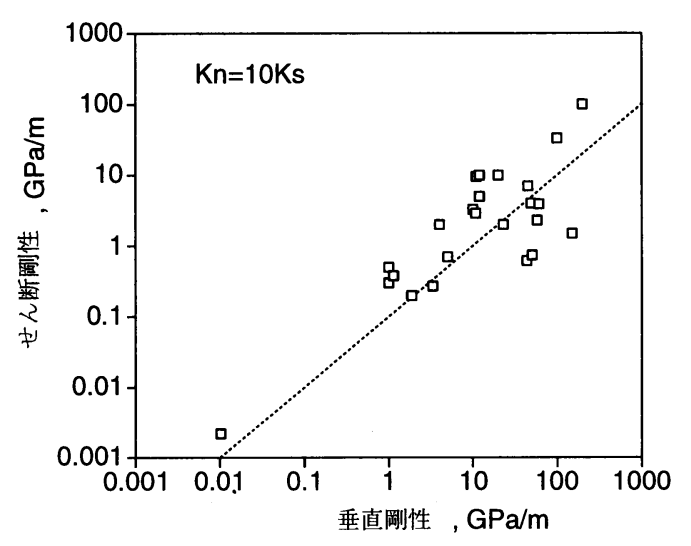

図一13 既往安定解析において設定された不連続面の 垂直剛性とせん断剛性の相関性

ができた.

基質部の岩の夕イプや圧縮強度やせん断履歴, 垂 直応力などによって, 不連続面の変形特性 $(K n, K s$, $i ）$ および強度特性（ $\phi, C)$ が大きく変わることが 室内試験によって分かる ${ }^{14)}$. 図一 12 は, 著者らと海 外の研究者が実施したせん断試験の結果をまとめて プロットしたせん断剛性と垂直応力との関係を一例 として表す.頁岩と砂岩の場合, 両者がほほ比例的関 係にあるが，凝灰岩の場合は壁面風化度などによっ てせん断剛性が大きく変動する. 同じ垂直応力下で あっても岩のタイプによって, また, 同じタイプの岩 の不連続面であってもせん断剛性が垂直応力に応じ てばらつきが大きいため, 全体には明瞭な相関関係 を見い出すことは困難であることが分かる.

\section{（3）既往の安定解析における特性値の考察}

不連続体解析手法の内, 個別要素法は不連続面に よって区切った塊状岩体 (ブロック)の大変位, 大回 転およびこれに伴う不連続面の完全な分離が許容さ れること, 各ブロックは非線形構成則に基づく変形 体を取り扱うために離散化されるなどの特徴を有す るため，実務的設計にも利用されるようになってき た. しかしながら, 最近発表された個別要素法による 解析例を調べたところ, 実際の試験結果に基づいて 不連続面の特性值を忠実に決定している例はごく少 数であった $\left.{ }^{2)}-10\right)$. 図ー13は，せん断試験を行わず に経験的に決定された垂直剛性, せん断剛性の入力 值の例を示す．ほとんどの解析では，Knを $K s$ の約 10 倍を中心として設定していることがこの図より 分かる. Bartonらも $K n$ は $K s$ の 10 倍であると主張 している ${ }^{29)}$ が，その根拠は明確ではない.

著者らの試験結果によれば（図一12), 基質部の

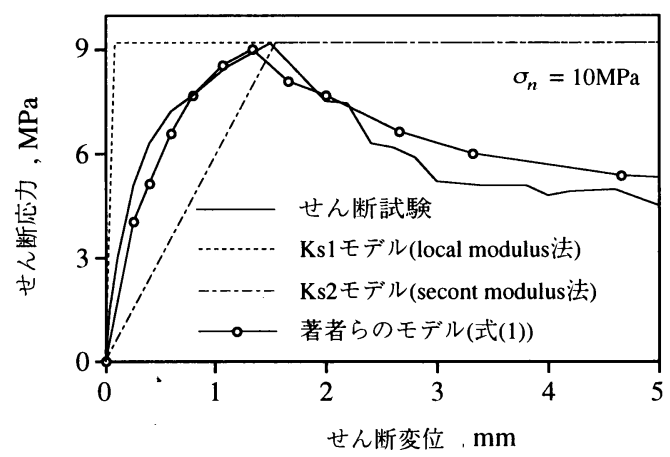

図－14 せん断試験結果と各せん断剛性の比較

\begin{tabular}{lr} 
表-4 & $\mathrm{Ks}_{1}$ と $\mathrm{Ks}_{2}$ の值 \\
\hline $\mathrm{Ks}_{1}$ & $92.0(\mathrm{MPa} / \mathrm{mm})$ \\
$\mathrm{Ks}_{2}$ & $6.1(\mathrm{MPa} / \mathrm{mm})$ \\
\hline
\end{tabular}

岩の圧縮強度が 70MPa 以下の頁岩や砂岩, 溶結凝灰 岩の場合, $K n / K s$ が $4 \sim 30$ と幅広く変化することが 分かり, 他の特性值にも同様な傾向が見られた。した がって, 定性的な評価に止まらず, 解析結果の実用性 を考えるには, 実際の現場条件に基づいて, 本論文に 示すような室内試験と評価法によって，不連続面の 挙動モデルとその特性値を正しく求める必要がある と思われる。

\section{6. せん断剛性の非線形性とその影響}

室内せん断試験によれば, せん断応力一せん断変 位の関係には, 前述のCoulomb滑りモデルでは表現し 得ないような非線形性が見られる場合がある（図一 9 (a)を参照) 。せん断応力ーせん断変位の関係を表 わす特性值がせん断剛性であり，前述のようにせん 断変位の増分に対するせん断応力の増分の比で定義 されることから, せん断応力一せん断変位の関係の 非線形性は，せん断剛性の非線形性とも言える。せ 几断剛性の非線形性は, ピーク時までのみならず, ピーク後においても考えられる。ここでは, 線形と しての取り扱いが簡便性を有しながらも，不連続面 の挙動評価の適切性という観点から, せん断剛性の 非線形性に着目し，岩盤構造物の変形挙動に与える せん断剛性の影響を明らかにすることを試みる。

\section{（1）せん断剛性の決定}

前章で述べたlocal modulus法やsecont modulus法は いずれもピーク時までのせん断挙動が線形であるこ とを仮定しており, 実際のせん断応力一せん断変位 


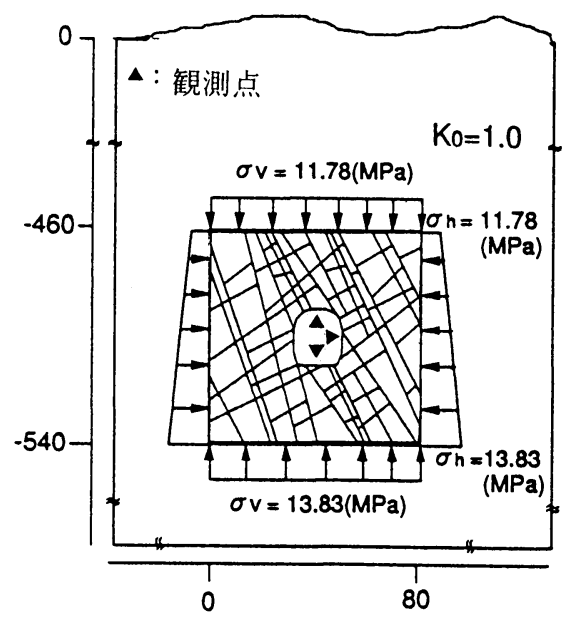

図-15 空洞掘削シミュレーションのモデル

表-5 空洞周辺地山の物性値

$\begin{array}{ll}\text { ヤング係数 } & 7.0(\mathrm{GPa}) \\ \text { ポアソン比 } & 0.25 \\ \text { 質量密度 } & 2.61\left(\mathrm{~g} / \mathrm{cm}^{3}\right)\end{array}$

表ー6 著者らのモデルに対する内空変位の比率の比較

\begin{tabular}{cccc}
\hline 観測点 & 著者らのモデル & $\mathrm{Ks}_{1}$ モデル & $\mathrm{Ks}_{2}$ モデル \\
\hline 天盤部 & $1(0.19)$ & 0.84 & 2.95 \\
側壁部 & $1(0.44)$ & 1.14 & 2.11 \\
底盤部 & $1(0.31)$ & 1.27 & 3.03 \\
\hline
\end{tabular}

( )内の数值は変位量, 単位はmm

の関係が線形的である場合は,どちらもほぼ同一の $K s$ 得られよう。しかし，それが曲線的，即ち，非 線形的である場合は，決定方法に依存してかなり異 なるKsが得られると考えられる。さらに，どの点を 用いて $K s$ を求めるか，またピークの有無などによっ てもその決定方法が一義的ではない.

以下に，砂岩に包含した自然の不連続面の試験体 を用いて垂直応力 $10 \mathrm{MPa}$ の一定垂直応力において実 施された室内せん断試験の結果（図一-14）を利用 して，せん断剛性の決定とそれによる影響効果を考 察する。試験はせん断変位 $20 \mathrm{~mm}$ までの単調載荷に より実施されている。図ー14 に示したように，せ ん断応力一せん断変位の関係は, 非線形性を有する ことが分かる。まず， local modulus法により決定し たせん断剛性を Ks，とし，曲線上の原点の接線の傾 きとして定義する， secont modulus法により決定した
せん断剛性を $\mathrm{Ks}_{2}$ として, せん断応力一せん断変位 曲線上の原点とピーク点を結んだ直線の傾きとして 定義する。それぞれの方法により決定された值を 表ー 4 に示す. $\mathrm{Ks}_{1} ， \mathrm{Ks}_{2}$ をCoulomb滑りモデルのパ ラメータとして用いる場合，本論文ではそれぞれ $\mathrm{Ks}_{1}$ モデル，Ks，モデルと称し，図一 14 に試験結 果と重ねて示す.これより，Ks 1 は $\mathrm{Ks}_{2}$ の約15倍で あり，決定方法の違いによりせん断剛性がかなり異 なることが確認できた。因って，せん断剛性に線形 性を仮定した挙動モデルを適用した場合, せん断挙 動が適切に表現されない可能性があり，これが誤差 発生の要因になると考えられる。次に, 式（1）に よりモデル化されたせん断応力一せん断変位の関係 も図一 14 に重ねて示す。せん断剛性には非線形性

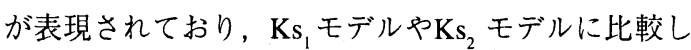
ても，せん断試験の結果を比較的忠実に表現してい ることが言えよう。

\section{（2）空洞掘削シミュレーションによる比較}

せん断剛性の取扱い方法の違いによる解析結果の 相違を比較することにより，せん断剛性の非線形性 の影響を検討する。ここでは，不連続性岩盤内に立 地のある空洞の掘削解析を個別要素法により実施す る.

解析モデルは，中心が地表面より500 $\mathrm{m}$ の深さに 位置する高さ $22 \mathrm{~m}$, 幅 $18 \mathrm{~m}$ の地下空洞であり,これ を図ー15に示す。地山としての花崗岩は弾性体と 見なし，その物性值を表一 5 に示す。解析領域は, 空洞寸法の $4 \sim 5$ 倍を対象と考えて $80 \mathrm{~m} \times 80 \mathrm{~m}$ と し, 境界条件は, この領域の周囲を岩盤と同一の物 性値を有する弾性体の無限地盤とした。不連続面の 力学的特性として, 図一 14 に示したKs 、モデルと $\mathrm{Ks}_{2}$ モデル，式（1）で示した著者らのモデルを用 い，これ以外はせん断試験結果を前述した方法によ り整理して, $K n=100 \mathrm{MPa} / \mathrm{mm}, C=0.0 \mathrm{MPa} / \mathrm{mm}^{2}, \phi$ $=42^{\circ}$ と求められた。これらの物性值は解析領域に おける個々の不連続面に適用する。 また, 図一15 に基づく不連続面の長さは $7.6 \mathrm{~m}$ と算定され，供試体 の寸法との関係について, Bartonらの提案式(6) を参 考とする。なお, Coulomb滑りモデルや著者らのモ デルは個別要素法における不連続面の構成則に組み 込まれている24)-26). シミュレーションの手順は，側 圧係数 $K_{o}=1.0$ とした初期地山応力分布を再現させ た後, 空洞壁面上で掘削相当応力を $100 \%$ 解放し た。空洞開削後, 最終的に平衡が達成された状態に おいて，適用した各モデルによる結果を比較した。

まず，不連続面のせん断変位の分布を比較するた めに，得られたせん断変位の大きさを不連続面に 
著者らのモテル

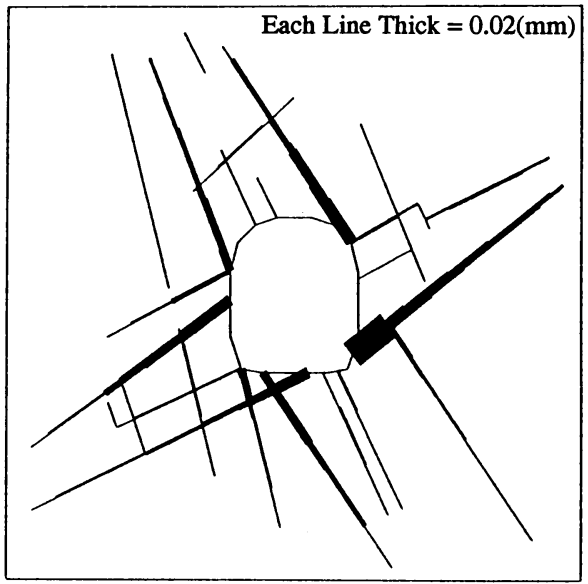

Max Shear Disp. $=0.459(\mathrm{~mm})$

Ks1モテル

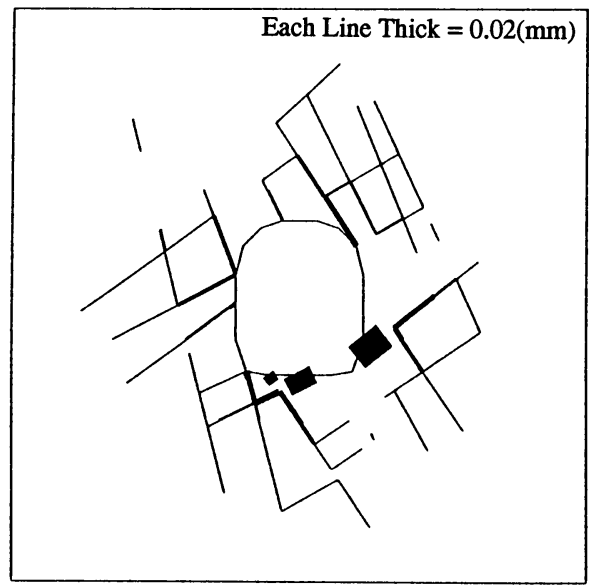

Max Shear Disp. $=0.449(\mathrm{~mm})$

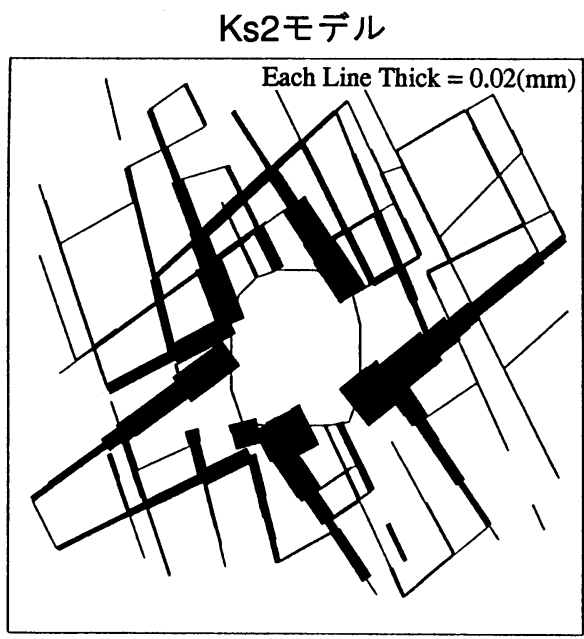

Max Shear Disp. $=0.769(\mathrm{~mm})$

図一16 不連続面のせん断変位の比較
著者らのモデル

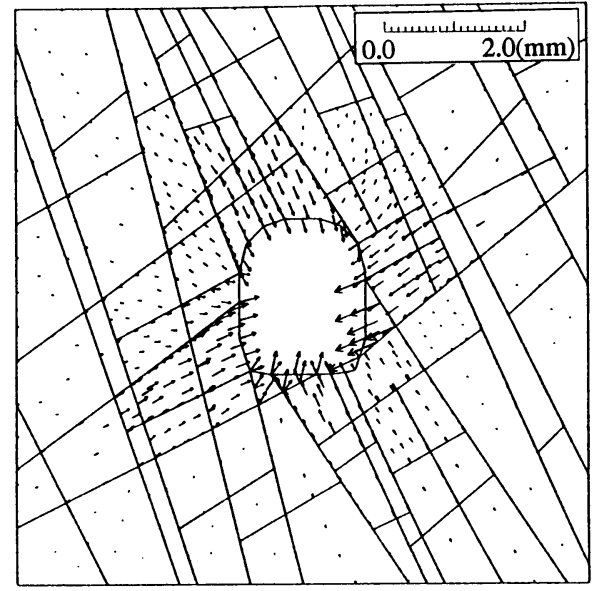

Maximum $=0.473(\mathrm{~mm})$

Ks1モテル

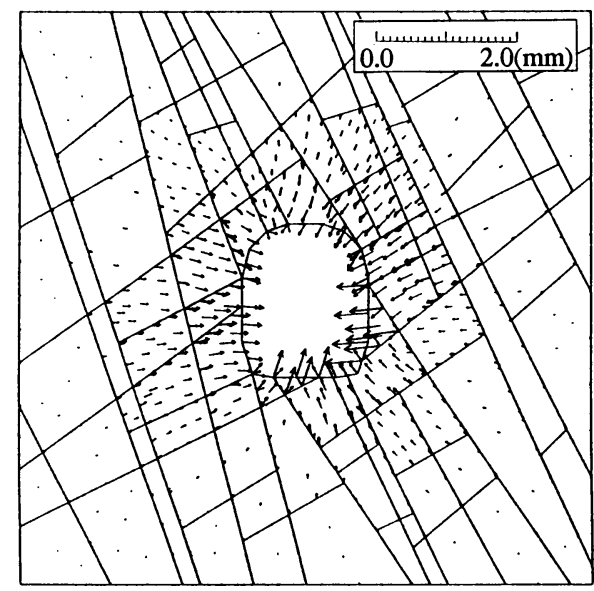

Maximum $=0.541(\mathrm{~mm})$

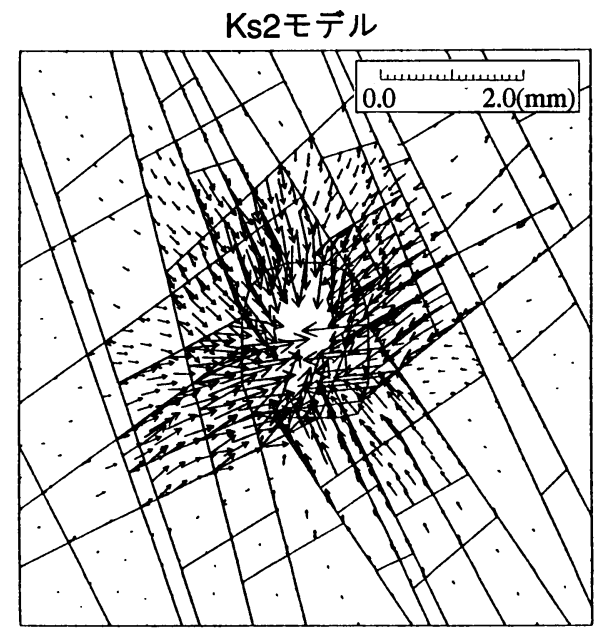

Maximum $=1.008(\mathrm{~mm})$

図-17 空洞周辺岩盤の挙動の比較 
沿った線の幅で表現した結果を図ー16に示す。 Ks，モデルによるせん断変位が空洞のすぐ近傍に生 じ，変位量も小さかったのに対して， $\mathrm{Ks}_{2}$ モデルで はせん断変位の発生は空洞幅の約 3 倍ほど奥部まで 広がり, 最大せん断変位量も著者らのモデルによる 結果の約1.7倍となった。これは， $\mathrm{Ks}_{2}$ モデルでは著 者らのモデルとKs，モデルに比べて不連続面のせん 断剛性がかなり低く算定され，せん断に対する抵抗 が弱くせん断変形を生じ易くなったためと考えられ る. 次に, 空洞周辺岩盤の挙動を比較するために, 変位ベクトルを図ー17に示す。著者らのモデルと $\mathrm{Ks}_{1}$ モデルとの間ではほぼ同じ変形挙動が得られて いるが, $\mathrm{Ks}_{2}$ モデルによる最大内空変位が著者らの モデルに比べて約 2.1 倍となる．比較するために， $\mathrm{Ks}_{1}$ モデル，Ks $\mathrm{K}_{2}$ モデルにより得られた内空変位を著 者らのモデルによる内空変位で正規化した結果を 表ー6に示す。これより著者らのモデルとKs，モデ ルは空洞の天盤部，または側壁部，底盤部において の変位に約 $15 \%$ 25\%の差があったが, $\mathrm{Ks}_{2}$ モデル では著者らのモデルの 2 ～倍の変位が得られてお り, せん断剛性の定義方法や非線形性の違いが内空 変位に敏感に反映されていることが分かる.

\section{7.おわりに}

本論文は, 個別要素法などの不連続体解析に必要 とする自然の岩盤不連続面の挙動特性を表す単一不 連続面の力学的挙動モデルの選定およびその特性值 を定量的に決定する一連のプロセスを示した。これ は, 種々の現場応力状態, せん断履歴が再現できるよ うに製作された室内力学特性試験の結果の利用を基 本とするものである.また, 実際に用いた十数種類の 自然の岩盤不連続面の特性値の相互関係を考察し, 既往の解析における問題点を指摘した。不連続面の 賦存条件の複雑さや複数の影響因子が絡み合ってい ることから，特性值は実際の現場の状況に近い条件 で試験的に求めるべきであると考える。

不連続面の力学的挙動モデルにピークせん断応力 までの領域におけるせん断剛性の非線形性を考慮す ることによる影響効果を調べてその必要性を検討す るため, 個別要素法による空洞掘削シミュレーショ ンを例とし，線形のせん断剛性と非線形性を忠実に 考慮できる著者らのモデルによるせん断剛性を適用 して比較した結果, せん断剛性の定義方法や非線形 性の違いが変形挙動に敏感に反映されることが分っ た。以上より，せん断剛性に非線形性が見られる場 合は，せん断剛性の適切な非線形性を考慮した不連 続面挙動モデルの適用が必要であると考える。ま
た,ここに見られるようなせん断剛性の非線形性を 理論的に表現することは現在のところ困難であり， 不連続面の室内せん断試験結果を忠実に再現するこ とを意図して定式化した著者らのモデルの有効性が 示されたと考える。

本論文に示した岩盤不連続面の挙動モデルの選定 とそれに対応した力学的特性值の決定のための一連 のプロセスは, 個別要素法など不連続体解析手法の 信頼性の向上に寄与するものであると考えられる.今 後は, 様々の種類の岩に包含された不連続面の力学 的特性の総括に基づき，実務的岩盤解析のための データベースの作成と実際現場の設計評価への適用 などを行っていきたい。

\section{参考文献}

1) Cundall,P.A. : Distinct element models of rock and soil structure, Analytical and Computational Methods in Engineering Rock Mechanics, 129- 163, 1987.

2) Jing,L. \& Stephansson,O. : Distinct element modelling of sublevel stoping, Proc. of 7 th. Int.Cong. Rock Mech, Aachen, 741- 746, 1991.

3) Hart,R.D. \& Lemos,J.V. : Numerical analysis of explosioninduced fault motion, Proc. of 29th US Rock Mech. Symp., 1988.

4) Kinashi,H., Amano,S., Tsuchihara,H., Yoshida,H. \& Michihiro,K. : Numerical study on reinforcement effect of cable bolt in discontinuous rock mass, Environmental and Safety Concerms in Underground Construction, Seoul, 553558, 1997.

5) Zhu,W., Chen,W. \& Wang,B. : Numerical simulation and experimental study of excavation and anchoring support of underground chmbers in jointed rockmass, Environmental and Safety Concerms in Underground Construction, Seoul, 565- 570, 1997.

6) Fowell,R.J. \& Ma,S.J. : Numerical stability analysis of a large cavern in weak rock, Environmental and Safety Concerms in Underground Construction, Seoul, 293- 298, 1997.

7) Lanaro,F., Barla,G., Jing,L. \& Stephansson,O. : Continuous and discontinuous modelling of the Corvara cliff, Eurock'96, Torino, 583- 588, 1996.

8) Zhu,F., Stephansson,O. \& Wang,Y.: Stability investigation and reinforcement for slope at Daye Open Pit Mine, China, Eurock'96, Torino, Italy, 621- 625, 1996.

9) You,K., Moon,C. \& Kim,B. : A numerical analysis for a hard rock tunnel in a mountain area considering discontinuities, Proc. Korea-Japan Joint Symp. on Rock Eng., Seoul, 311-317, 1996.

10) 藤原吉美, 堀江正人, 瀬岡正彦, 平川芳明, 森 聡: 大規模岩盤地下空洞の施工実績に基づく不連続体解析 法の適用に関する検討, 第 10 回岩の力学国内シンポ ジウム論文集, 569-574, 1998. 
11) Bandis,S.C., Lumsden,A.C. \& Barton,N.R. : Fundamentals of rock joint deformation, Int. J. Rock Mech. Min. Sci. \& Geomech. Abstr. 20(6), 249- 268, 1981.

12) Brown,S.R. \& Scholz,C.H. : Closure of rock joints, J. of Geophysical Research 91(B5), 4939- 4948, 1986.

13) Amadei,B. \& Wibowo,J. : Applicability of existing models to predict the behavior of rock joints under different boundary conditions, Proc. of 2nd Int. Conf. on Analysis of Discontinuous Deformation, 36- 106, 1997.

14）蒋 宇静, 江崎哲郎, 金子和宏, 野崎明人, 笹田俊治: 自然の岩盤不連続面のせん断特性の実験的評価，第 10 回岩の力学国内シンポジウム論文集, 73-78, 1998.

15) Stephansson,O. \& Jing,L. : Testing and modelling of rock joints, Mechanics of Jointed and Faulted Rock, Balkema, 37- 47, 1995.

16) Barton,N., Bandis,S. \& Baktar,K. : Strength, deformation and conductivity coupling of rock joints, Int. J. Rock Mech. Min. Sci. \& Geomech. Abstr. 22, 121- 140, 1985.

17) Goodman, R.E. : Methods of geological engineering in discontinuous rocks, West Publishing Company, 1976.

18）江崎哲郎, 三谷泰浩, 亀田伸裕: 岩盤不連続面のせん 断一透水同時試験装置の開発, 資源と素材, Vol.112, 213-218, 1997

19) Plesha M. E. : Rock Joints, Theory, Constitutive Equations, Elsevier Science, 1995.

20）江崎哲郎, 蒋 宇静, 杜 守継, 三谷泰浩, 和田圭仙： 岩盤不連続面の表面形状変化とせん断特性との関係, 第 10 回岩の力学国内シンポジウム論文集, 79-84, 1998 .
21）赤井浩一, 川本眺万, 大西有三共訳:不連続性岩盤の 地質工（R.E. グッドマン原著），森北出版株式会社, 1978.

22) Saeb,S. \& Amadei,B. : Modeling rock joints under shear and normal loading, Int. J. Rock Mech. Min. Sci. \& Geomech. Abstr. 29, 267-278, 1992.

23) Cundall, P.A. \& Lemos, J.V. : Numerical simulation of fault instabilities with a continuously-yielding joint model, Rockbursts and Seismicity in Mines(Fairhurst, C. Ed. Rotterdam, A.A. Balkema), 147-152, 1990.

24) 中川光雄, 蒋 宇静, 江崎哲郎: 岩盤不連続面の力学 的挙動モデルの提案について, 第 28 回岩盤力学に関 するシンポジウム講演論文集, 194-198, 1997.

25）中川光雄, 蒋 宇静, 江崎哲郎: 岩盤挙動解析におけ る不連続面のせん断剛性の非線形性の効果, 第 10 回 岩の力学国内シンポジウム論文集，163-168, 1998.

26) 中川光雄, 蒋 宇静, 江崎哲郎: 地下空洞安定解析に おける岩盤不連続面の力学的挙動モデルの提案と適 用，土木学会論文集，No. 603/III-44, 53-66, 1998.

27) CANMET : Determination of strength properties of rock discontinuities by direct shear test, Pit Slope Manual, 3744, 1981.

28) Hencher,S.R. \& Richards,L.R. : Laboratory direct shear testing of rock discontinuities, Ground Engineering, 24- 31, 1989.

29) 蒋 宇静:NGI (ノルウェー地盤工学研究所) ·地盤挙 動解析グループとの交流メモ，1997.8.

(1998.8.12. 受付)

\title{
QUANTITATIVE EVALUATION OF MECHANICAL PROPERTIES OF THE NATURAL ROCK JOINTS FOR ANALYZING BEHAVIOR OF STRUCTURES IN DISCONTINUOUS ROCK MASSES
}

\author{
Yujing JIANG, Mitsuo NAKAGAWA and Tetsuro ESAKI
}

\begin{abstract}
The appropriate modeling of mechanical behavior of a discontinuity and the quantitative determination of its characteristics have an important role on evaluating the stability and deformational behavior of structures in the discontinuous rock masses. This paper is to present the laboratory test techniques and a rational procedure for the determination of deformational characters and strength of natural rock joints. The problems concerning with the assessment of these characteristics in the previous analysis are also pointed out based on the investigation of the shear tests conducted on several types of real natural joints. The distinct element analyses, in which both liner shear stiffness and non-linear one are introduced for the same ground conditions, are also carried out to clarify the effect of non-linearity of shear stiffness on the deformational behavior of rock structures.
\end{abstract}

